Marta Szymaniak and Kazimierz Więckowski

\title{
THE NATURE OF BOTTOM DEPOSITS IN SOME CHOSEN GOSTYNIN LAKES
}

Bottom deposits of the following three lakes selected from among several scores of such lakes in the Plock Basin, Central Pland, and belonging to the Gostynin Group were investigated in 1979 and 1982:

\begin{tabular}{lccc} 
& $\begin{array}{c}\text { Altitude } \\
\text { above sea } \\
\text { level metres }\end{array}$ & $\begin{array}{c}\text { Surface } \\
\text { area } \\
\text { hectares }\end{array}$ & $\begin{array}{c}\text { Maximum } \\
\text { depth } \\
\text { metres }\end{array}$ \\
\cline { 2 - 4 } 1. Lake Szczawińskie & 94.5 & 33 & 1.0 \\
2. Lake Gościąż & 64.4 & 45 & 25.8 \\
3. Lake Wikaryjskie & 65.0 & 66 & 13.5
\end{tabular}

With hardly any flowing movement observed in the three lakes under study, they are characterized by the fact that surface water supplies count little in the overall water balance and that basins of the lakes virtually resemble each other both hydrologically and geologically.

Similarly to other lakes existing in this region of the last glaciation, also these ones owe their origins to the thermokarst processes, as they were materializing over the Alleröd-Preboreal Period, i.e. twelve to ten thousand years ago, from the melting, dead or winter, ice-blocks which during the recession-phase of the last glacier preservingly filled the intricate system of extramarginal gullies and valleys moulded in the fluvioglacial sand formations covering the area with a $20-$ to $40-\mathrm{m}$ thick layer.

Research work was carried out on site from the ice surface. At a point in the south-eastern part of Lake Wikaryjskie, located over the central area of a vast level bottom, a monolythic core of deposits of undisturbed stratification was brought up to the surface from a depth of five metres. It covered a full cycle of accumulation of the lacustrine deposits type carbonate-detritus-gyttja, 3.95 metres in thickness with an $0.15-\mathrm{m}$-thick layer of peat (dated to $10,360 \pm 200 \mathrm{BP}$ by the ${ }^{14} \mathrm{C}$ method) and another $0.9-\mathrm{m}$-thick strata of the grey poorly-washed sands underlying the former. The core measured five metres in total len'gth. 
A similar core of bottom deposits was collected from Lake Gościąż at a point 300 metres away from the eastern side of this lake, 7.7 metres in depth. It contained an 8.1-m-thick layer of the lacusrtine deposits representing in themselves on olive-grey carbonate gyttja, unfortunately without its lowermost part. Underlying the gyttja there was a 0.7-m-thick layer of sands containing a considerable percentage of the Miocene lignite fragments, a product of the washing process. This confirms to some extent the hypothesis that the original bottom of the lake basin, situated some fourteen metres below the present-day bottom of the Vistula River, goes back in its origins to the Miocene Period formations. The total length of the core was 8.8 metres.

A little wider in its scope was the research programme of Lake Szczawińskie. A core, 6.9 metres in length, was extraced from the southern, completely peatbogged, part of the basin. This consisted of a 2.3-m-thick layer of the sedge-cane peat, overlying another $4.25-\mathrm{m}$ -thick layer, of the carbonate-detritus gyttja, and included plenty of small mollusc shells, characteristic of the lithoral zones. In the lowermost part of the deposits there was a $0.05-\mathrm{m}$ peaty inclusion underpadded by a $0.2-m$-thick layer of the well-washed, grey sands. These sands were estimated by $\mathrm{Mr}$ and Mrs M. and W. Prószyński in the Laboratory of Geochronology, Warsaw University, by the thermoluminescenece method at approximately 56,000 years of age.

In the succeeding season, lacustrine deposits were mesaured for their thickness allong two perpendicular east-west and north-south cross-sections made through the lake at $200-\mathrm{m}$ intervals. At their crossing-point an 11-m-long core was collected from the central part of the basin. It covered a complete cycle of accumulation of the carbonate-gyttja with a thickness of 9.7 metres. The gyttja was underlaid by two peaty layers, both of them 0.4 metres thick, with yet another padding below of 0.6 metres in thickness of the initially, peatbogged and then well washed, grey sands of the substrate. The age of the lower portion of sands situated at a depth of 10.38 to 10.48 metres was estimated by the thermoluminescence method at approximately 112000 years of age.

In the Geoecological Laboratory, Department of Geography and Regional Studies of Warsaw University, bottom deposits of the lakes under investigation were analysed for their contents. Bottom deposits of Lakes Szczawińskie and Wikaryjskie were subjected to quantitative analysis to determine the content of $\mathrm{CaCO}_{3}$ and to find out the weight-loss on ignition after roasting the material at $550^{\circ} \mathrm{C}$ to dry organic matter residue. Bottom deposits of Lake Gościąz were checked only for their weight-loss on ignition. 
The basin of Lake Szczawińskie, which has been undergoing for some time now a rapid process of degradation (its surface area has shrinked from 48 to 33 hectares for the last sixty years i.e. almost by one third, and its depth is only 0.5 to 1.0 metres now), remains nearly completely filled with the deposits of olive-grey, soft, amorphous carbonate-gyttja extremely homogenous throughout the entire vertical cross-section of the deposits. It is only the lower layer, two metres thick, that exhibits several weak signs for the presence of a very fine and regular microlamination.

Findings of the analysis have fully confirmed this homogeneity (see Fig. 2). Both the $\mathrm{CaCO}_{3}$ curve with its 60 to 82 percentage (73 per cent on an average), and the organic matter curve with its 10 to 25 percentagie data (18 per cent of the solid residue on an average), except for the topmost and lowermost parts of the deposits which is quite normal, are extremely regular in their shapes. The percentage of organic matter rises slowly as the basin is being filled with the bottom deposits, the percentage of $\mathrm{CaCO}_{3}$ showing a downward trend (proportionately) at the same time. It must be stressed that the organic matter and $\mathrm{CaCO}_{3}$ curves represent in themselves quite unique, almost ideal, exam. ples of a negative correlation existing between the two most fundamental components in the bottom deposits of most lakes as found in the post-glacial regions of ncrth-eastern Europe. Noteworthy appears to be also the high average rate of accumulation, being approximately $1 \mathrm{~mm}$ a year and in the Polish case $0.7 \mathrm{~m}$ respectively.

To sum up, the macroscopy of bottom deposits and relevant analytical findings tend to corroborate the fact of the exceptionally stable conditions of accumulation and this means also general stability of the thermal and hydrochemical regime at Lake Szczawińskie. It is possibie that such a stability might have been an outcome of the specific hydrological situation, and of hydrogeological lake-basins in particular. This lake, as a matter of fact, has been aided by the subterranean waters and in their number also subtertiary waters characterized by chemical and thermal stability.

Macroscopic character of bottom deposits in Lake Gościąz, as illustrated by the shape of the organic matter curve, resembles that of Lake Szczawiniskie. Certain divergencies come true in the upper stretch of the curve only, but this can be explained by too little consideration being given to the topmost semiliquid layer present in the lacustrine deposits of Lake Gościąż.

Quite different seems to be the image as presented by the analysis of Lake Wikaryjskie bottom deposits (see Fig. 2). Characteristic in 
this case is the periodicity with which organic matter has been accumulating in the bottom deposits. One can distinguish four cycles of varying duration, or different intensity of accumulation, clearly seen in the thickness of individual layers associated with these cycles. The lower part of each of them is marked by a drop in organic matter percentage (10 to 20 per cent). In the upper parts this percentage becomes higher, being 30 to 40 per cent. The $\mathrm{CaCO}_{3}$ percentage diminishes when proceeding towards the top of the deposits, ranging from 60 to 70 per cent in the lower part to 40 or 50 per cent in the topmost one. It is strange that no correlation seems to exist between the $\mathrm{CaCO}_{3}$ and the organic matter curves.

The characeristic, periodically variable, process of accumulation of the organic matter as well as the complete lack of correlation with the $\mathrm{CaCO}_{3}$ percentage curve seem to be an outcome of the specific local conditions exerting their influence on Lake Wikaryjskie catchment basin. But to explain this in more detail would require some further and more complex studies.

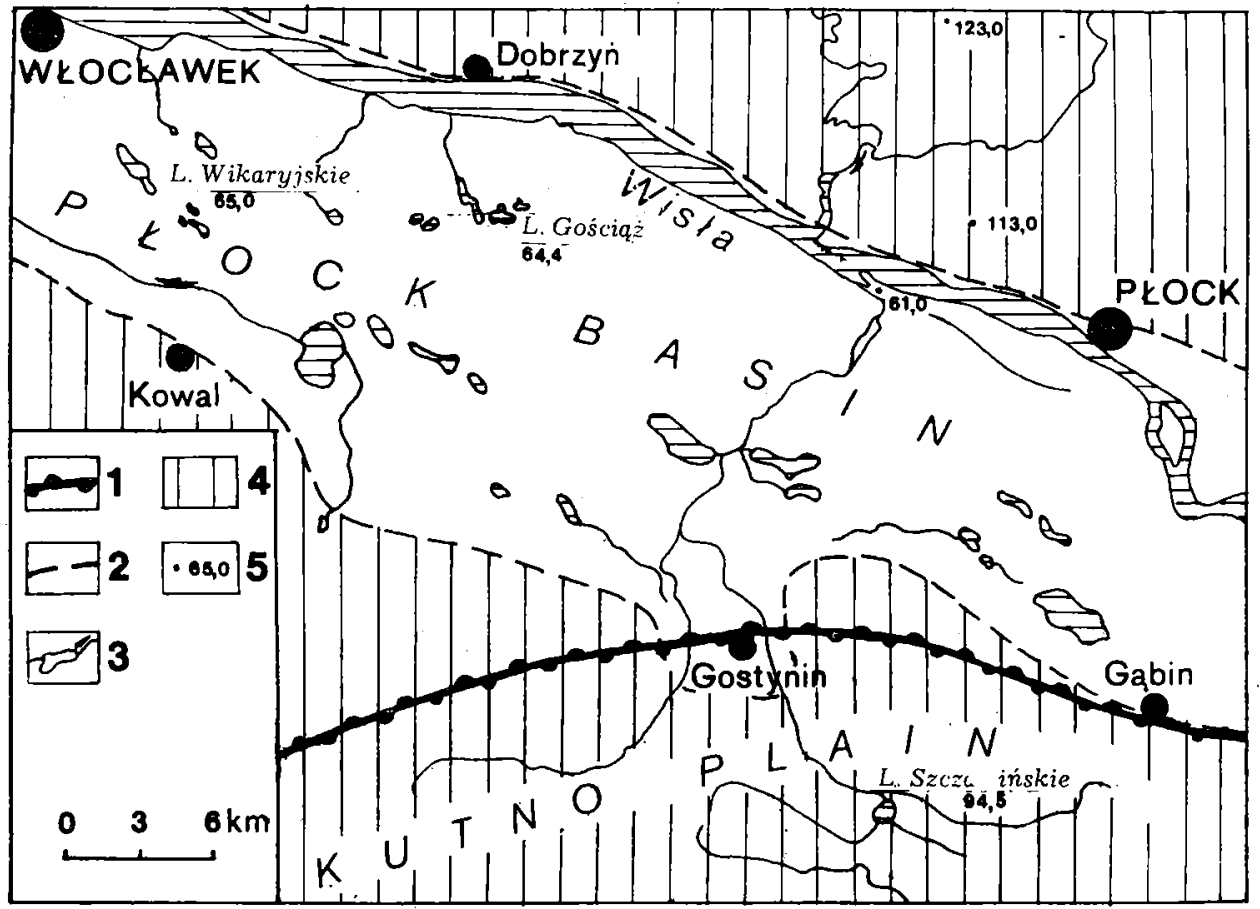

Fig. 1: Map showing position of the Gostynin Lakes

1. southern boundary of the würm glaciation

2. boundaries of the Plock Valley

3. rivers and lakes

4. morainic elevations

5. altitude obove sea level 


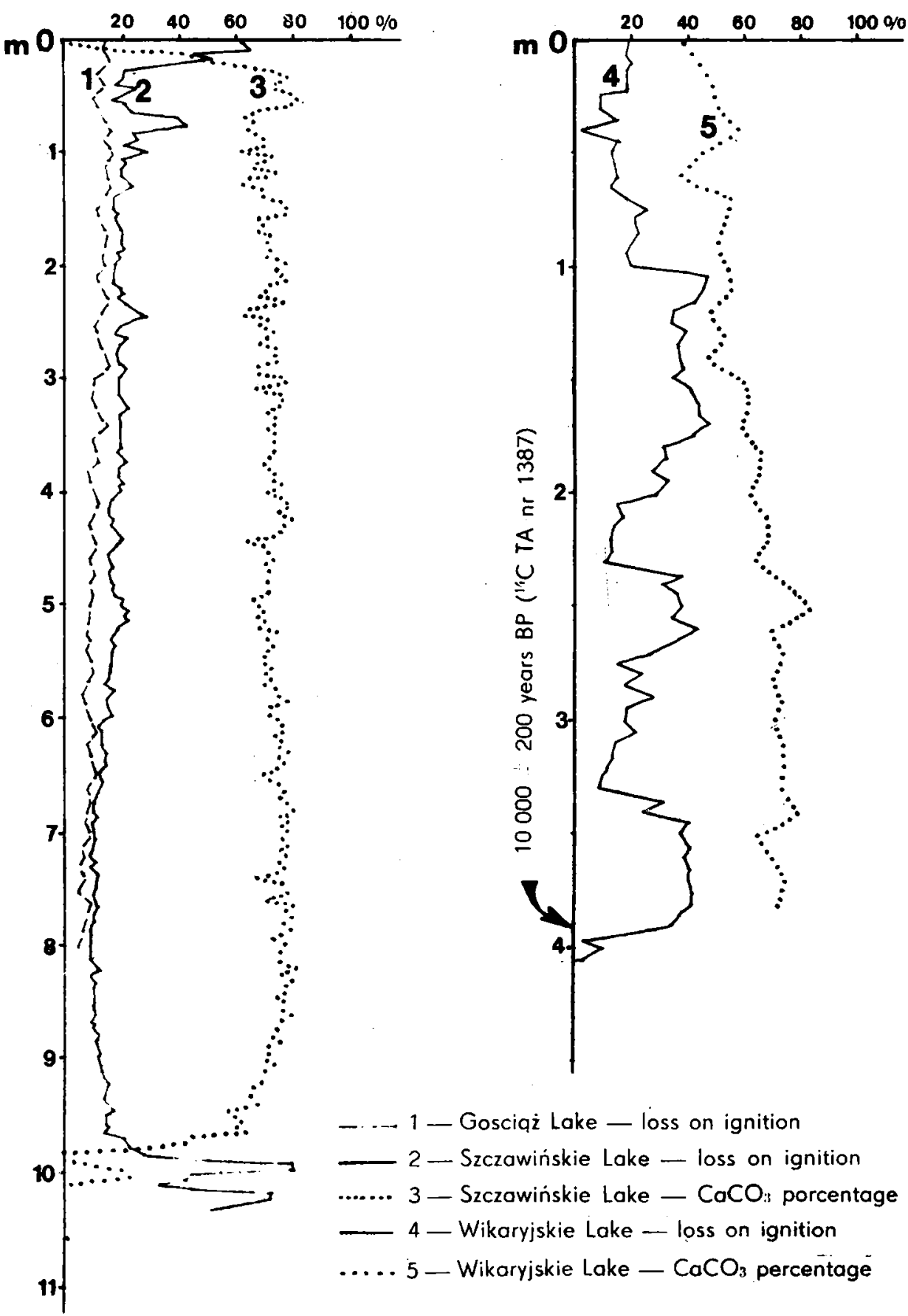

Fig. 2: $\mathrm{CaCO}_{3}$ percentage and loss on ignition in the case of Gostynin Lakes bottom deposits 
